\title{
Impact Evaluation of Training on Firms' Performance: The Case of the Small and Medium Enterprises in Vietnam
}

Nguyen Khanh Duy

University of Economics Ho Chi Minh City, Vietnam

Pham Tien Thanh

Ton Duc Thang University, Vietnam

Nguyen Thi Hoang Oanh

University of Economics Ho Chi Minh City, Vietnam

Nguyen Duy Tam

University of Economics Ho Chi Minh City, Vietnam

Truong Thanh Vu

Development Strategy Institute, The Ministry of Planning and Investment (MPI)

Doi:10.5901/mjss.2015.v6n2p399

\section{Abstract}

This paper aims to evaluate the impact of investment in human capital (off-the-job training) on performance of the small and medium enterprises (SMEs) using Propensity Score Matching (PSM) method with dynamic approach by analyzing the data from two surveys on the SMEs in Vietnam in 2009 and 2011. The results found that training has significantly positive impact on ROA in short term, but no impact on revenue and profit of the firms in short term and in the near future (one-or-two-year after training)

Keywords: impact evaluation, performance, propensity score matching, SMEs, training, Vietnam

\section{Introduction}

In recent years, there is a substantial progress in many industries where knowledge and well-trained workers play a key role in production. The accumulation of human capital plays an important role in explaining economic performance and long-term growth (Lucas, 1988). Although in organizations there is an increasing concern that training investments are justified by improved organizational performance (Salas \& Canon-Bower, 2011), it is difficult to find a strong evidence of this argument in the human resource literature. Many studies have tried to estimate the effect of training on firms' performance, but the results were not consistent (Black and Lynch, 2001; Storey, 2002; Dearden et al, 2006).

Although investment in human capital plays a very important role in enhancing the firms' competitiveness in the context of international integration and consequence of global economic crisis, local enterprises (especially SMEs) do not make an appropriate investment in human capital. According to Xuan Ngoc (2012), a survey of 437 managers and 335 enterprises showed that in 2010, the budget for training was equal to $7.13 \%$ of wage fund, which means the cost per worker was only VND389000. This percentage in 2009 was 6.89\%, implying that only VND313000 was spent on training for each worker. Le Thi My Linh (2009) stated that the majority of company owners have not been aware of the importance of training human resources, 59\% of the enterprises in HCMC do not have the documented training policies. Therefore, it results in rather low quality of human resource. GSO (2012) showed that in 2011, the proportion of unskilled workers was $84.4 \%$ in the Vietnam.

According to the Government's Decree 56/2009/ND-CP (Vietnam), the State offers support for SMEs in South Vietnam through Southern SME Technical Assistance Center. However, in 2011, the training in enterprises did not have 
any improvement; there were only 15 courses held by the center for 663 trainees. Xuan Ngoc (2012) stated that in fact, the companies often "hunt" skilled workers instead of training; and many enterprises are willing to spend on training activities but worried about the labors' "jumping" to another companies after training. Moreover, most of the enterprises have not evaluated the effectiveness of training activities and claimed that it is very difficult to conduct such activities.

The research on the impact of investment in human capital on firms' performance is highly necessary to enterprises, especially SMEs in Vietnam. This research used a quasi-experimental design with propensity score matching (PSM) method for analyzing the impact of this activity on performance. In order to achieve the research objectives, the research will focus on answering the following question: "How is the impact of human capital investment on the performance of SMEs?"

\section{Literature Review}

\subsection{Theoretical background of the impacts of training on firms' performance}

Many studies in strategic human resource management (SHRM) provide models or analytical frameworks to explain the impact of investment in human capital (training) on organizations' performance. Wright and McMahan (1992) developed an analytical framework linking human resource management practices to organizations' performance. On the basis of the research conducted by Wright and McMahan (1992), Tharenou et al. (2007) proposed a framework for the causal relationship between training and organizations' outcomes. (Figure 1)

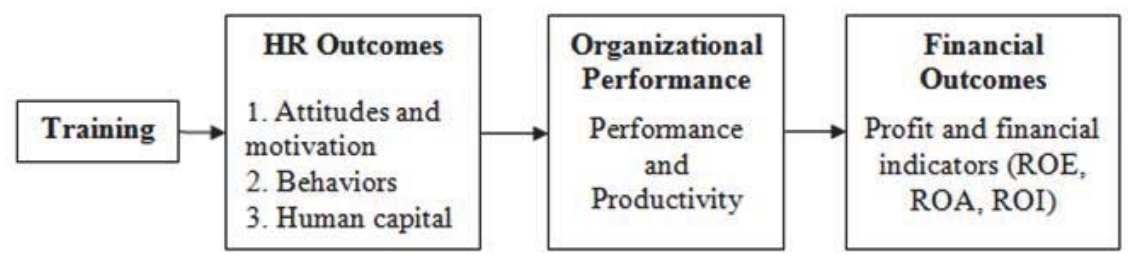

Figure 1. Theoretical Model by Tharenou et al. (2007)

The theoretical framework shown in Figure 1 implies an impact of training on organizations' performance. Nevertheless, theories of SHRM suggested that, alternative types of models also need to be investigated. Delery and Doty (1996) provided three other perspectives on the relationship between human resources practices and organizations' performance, including contingency perspectives, universalistic perspectives, and configurational perspectives. These perspectives can explain the impact of training on organizations' outcome in various approaches.

Universalistic perspective is considered to be the most fundamental. This perspective stated that there is a positive relationship between some HR practices such as formal training and organizations' outcome (Delery \& Doty, 1996). Basing on the universalistic perspective, training is believed to have a significant positive impact on organizations' performance.

Contingency perspective is considered to be more complicated than universalistic perspective because it takes into account the interactions between HR practices and organizational factors or contextual factors (Delery \& Doty, 1996). That is, training activities should be conducted together with organizational strategies in order to reap better outcome (Schuler, 1989).

Configurational perspective states that there are ideal types of HR practices that can result in better outcome (Ostroff \& Bowen, 2000). Barney and Wright (1998), Baron and Kreps (1999), Lepak and Snell (1999) suggested that the effectiveness of training will be enhanced when training activities are conducted in combination with other complementary HR practices such as careful screening and selection of potential and trainable employees.

\subsection{Empirical Studies}

\subsubsection{Impact of human capital (training) on firms' performance}

The impact of human capital investment (especially training activities) on firms' performance has been studied in many countries. Dumas and Hanchane (2010) evaluated the impact of training programs by the Moroccan on the performance of Moroccan companies. The results found that these training programs enhance firms' competitiveness and 
performance. Their finding also emphasized that training activities will capture better outcomes when they are considered as part of HR development strategies. Storey (2002) asserted that training has positive impact on firms' performance for the case of big firms in the US, but this impact is uncommon to SMEs in the UK. In Vietnam, Nguyen, Ngo and Buyens (2008) surveyed 196 companies and indicated that firms which implement training activity in 2006 increased sales and productivity in both manufacturing and non-manufacturing sectors.

The above researches mainly applied OLS method with cross-sectional data, or GMM method with panel data. These methods could not measure the true impact of training on firms' performance when the selection of firms with or without training activities is not a random experiment. Very few studies applied PSM method to investigate the impact of training activities on firm performance although this is the most common technique of evaluation impact of programs, projects, policies, and discussed in the training curriculum of World Bank by Khandker et al. (2010). Therefore, this research employed PSM to evaluate the impact of training on firms' performance in order to reduce selection bias.

\subsubsection{Determinants of investment in human capital (training)}

In order to evaluate the impact of human capital investment (training) on productivity, the firm performance, or wages; it is the most important to construct a model that reflects the determinants on human capital investment via using Logit or Probit model. The following studies showed the determinants of the human capital investment by firms.

Forrier and Sels (2003) indicated that the investment in training was explained by number of employees, types of industry, characteristics of the internal labor market, number of contracts, number of fixed-term contracts, hours of agency work per employee, turbulence or change in the number of staff, inflow, and outflow.

In as research for the case manufacturing SMEs in Australia, Jones (2005) found that the factors that affect the probability of providing training are introduction of change in technology, documented formal business plans, introduction of business improvement programs (QA, JIT), change in business structure and employment size, and innovation.

Hansson (2007) found that that the most important factor in determining the provision of training is company management. Hansson (2007) also found other factors that affect the provision of training, including whether firms analyses the need of training $(+)$, whether firms has a written training policy $(+)$, whether the company focuses on internal promotion (-), firms' unionization level (-), firm's past profitability (+), employees' age (-), employees' educational level (+).

Guidetti and Mazzanti (2007) constructed the model of influential factors on training activities comprising the five main groups: firm characteristics, internal labor market factors, workforce characteristics, techno-organization innovation, and performance.

\section{Method}

\subsection{Research objectives and hypothesis}

This study evaluates the impact of the human capital investment (off-the-job training) on various indicators reflecting the firm performance. Three main hypotheses in this research include:

$\mathrm{H}_{1}$ : off-the-job training increases revenue of SMES

$\mathrm{H}_{2}$ : off-the-job training results in higher profit of SMEs

$\mathrm{H}_{3}$ : off-the-job training improves ROA of SMES

These hypotheses need to be tested because many big companies have recently paid attention to training activities (Xuan Ngoc, 2012), and Tran Kim Dung (2011) stated that in Hochiminh City, training activities in such enterprises are wasteful and inefficient. Nguyen Tung (2012) found that there is a positive relationship between training activities and growth rate of profit (correlation=0.54). In Vietnam, Nguyen, Ngo and Buyens (2008) surveyed 196 companies and indicated that firms which implement training activity in 2006 have increased sales and productivity in both manufacturing and non-manufacturing sectors. If the hypothesis is accepted via using a significant method, it will enable the enterprises to trust in the training activities as well as enable the government to promote the training support for SMEs.

\subsection{Research Methodology}

This research applies qualitative methods to answer the research question. The main method is Propensity Score Matching (PSM). PSM designs a comparison group based on a model of probability of participation in training by using observed characteristics. The participants are then matched, on the basis of this probability or propensity score, with non- 
participants. The average treatment effect is then calculated using the mean in difference in outcomes between these two groups (Khandker et al., 2010).

This research does not employ traditional methods, such as multiple regressions, to investigate the impact of investment in human capital on productivity because such methods are only reasonable with respect to randomized experiments. The greatest difficulty of impact evaluation is to identify the outcome without the program; in particular, the difficulty in this research is to identify the potential outcome if the enterprises do not invest in human capital. In reality, we cannot find an enterprise that both invest and does not invest in human capital at the same time. A lot of techniques for impact evaluation (such as PSM, DID, Match DID, etc.) help to construct counterfactual outcomes in order to compare with the enterprises which invest in human capital, and then the problem of causal effect of the programs/ associated policies on the outcome is settled (Khandker et al., 2010).

Table 1. The Expected Variables in Probit Model

\begin{tabular}{|c|c|c|}
\hline Description & Variable List & Note \\
\hline \multicolumn{3}{|l|}{ I Dependent variable } \\
\hline Investment in human capital (training) & & $\begin{array}{c}\text { Dummies } \\
(1=Y e s ; \\
0=\mathrm{No}) \\
\end{array}$ \\
\hline \multicolumn{3}{|l|}{ II Independent variables } \\
\hline 1 Total assets & Inassets & Continuous \\
\hline 2 Age of firm & firmage & Continuous \\
\hline 3 Industrial park/zone (IZ) & industrialpark & Dummy \\
\hline 4 Form of ownership/legal status & cooperative, Itd_jstock & Dummies \\
\hline${ }_{5}$ Percentage of managers, professionals, office workers (\%) & officeworkers casuallabour & Continuous \\
\hline Share casual labour force of total (\%) & 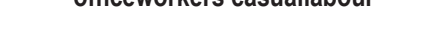 & Continuous \\
\hline 6 Turnover & turnover & Continuous \\
\hline 7 Business plan & businessplan, restructure & Dummy \\
\hline $\begin{array}{l}8 \text { Constraints to growth } \\
\text { Does the firm face any major constraints to growth? }\end{array}$ & constraints & Dummy \\
\hline 9 Negatively affected by the global economic crisis & crisis & Dummy \\
\hline 10 Member of one or more trade associations & association & Dummy \\
\hline 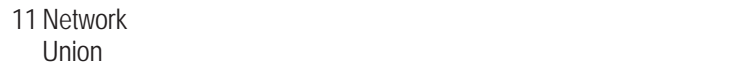 & network & Dummy \\
\hline $\begin{array}{l}12 \text { Does the enterprise have a local/plant level trade union/employee } \\
\text { representative organization? }\end{array}$ & union & Dummy \\
\hline $\begin{array}{l}13 \text { The long-term attachment } \\
\text { Buying social, insurance, health insurance for employees }\end{array}$ & healthsocialins & Dummies \\
\hline $\begin{array}{l}14 \text { Labor market } \\
\text { How does the enterprise hire workers? }\end{array}$ & newspaperad; ocalauthorities; emcenter & Dummies \\
\hline $\begin{array}{l}\text { Is there any difficulties in recruiting workers with the } \\
\text { required/appropriate skill level }\end{array}$ & diffrecruiting & Dummy \\
\hline 15 Percentage of short-term contracts (\%) & shorttermcon & Continuous \\
\hline 16 Research and development (R\&D) & R\&D & Continuous \\
\hline $\begin{array}{l}17 \text { Percentage of modern technology (\%) } \\
\text { Innovation }\end{array}$ & moderntechnology & Continuous \\
\hline Number of personal computers & computer & \\
\hline Sell products via e-trading & etrading & \\
\hline Purchase services from outside the enterprise & servoutside & Dummies \\
\hline 18 Automatic job rotation system & jobrotation & (and/or) \\
\hline Days of inventory & inventory & Continuous \\
\hline Environmental standards certificate & envstandard & \\
\hline $\begin{array}{l}\text { Major improvements in existing products or changed specification; } \\
\text { Introduction of new production processes/technology }\end{array}$ & improveproducts & \\
\hline $\begin{array}{l}19 \text { The firm has been involved in training courses supported by the } \\
\text { national or international organizations }\end{array}$ & foreigndonors & Dummy \\
\hline 20 Government assistance & govassistance & Dummy \\
\hline 21 Industry & $\begin{array}{l}\text { industry1, industry3, industry4, industry5, } \\
\text { industry6, industry7, industry8 }\end{array}$ & Dummies \\
\hline
\end{tabular}

Notes: Italic variables are dummies;

Based on the literature review and empirical studies about, the model of determinants of human capital investment in SMEs may include explanatory variables as shown in Table 1. In particular, the variables of firm and workforce characteristics, contract and policy are similar to the ones of other studies such as Guidetti and Mazzanti (2007), Forrier and Sels (2003) and Hansson (2007). On the basis of studies by Rosholm et al. (2005) and Hansson (2007), this study also constructs variables of unionization and network or regional factors in the model. Besides, the variables of labor 
market factors or technology innovation and business plans are similarly involved in this model as in the studies of Jones (2005), Guidetti and Mazzanti (2007).

All the variables in Table 1 will be put in to probit model to estimate the probability of investment in human capital. Khandker et al. (2010) stated probit or logit model is only considered intermediary step in PSM, but not the main focus. After estimating the probit model, this study will evaluate the impact of the human capital investment on productivity and indicators reflecting the firm performance via using PSM techniques (Stratification and Kernel Matching method with Bootstrapped standard errors ).

\subsection{Data description}

The data of SMEs is conducted by the Central Institute for Economic Management (CIEM) under Ministry of Planning and Investment, Institute of Labor Science and Social Affairs (ILSSA) under Ministry of Labor, Invalids and Social Affairs; Department of Economics (DoE), Copenhagen University; and Embassy of Demark in Vietnam.

This research uses the secondary data of SMEs in Vietnam in 2009 and 2011 collected by CIEM, ILSSA and DoE (completed in 2010 and 2012) for 10 cities/provinces in Vietnam; and the balance panel data was used in order to estimate the model. The training activities used for analysis might be conducted in the beginning of 2009, 2008, or before 2008, but mainly in 2008. The surveyed data includes both formal business (with business registration under Vietnam's Enterprise Law) and household business. However, this research only employs formal business.

\section{Results and Discussion}

The research analyzes the impact of training on performance using such financial criteria as revenue, profit and ROA. From the results of probit models (Appendix A), we can calculate the probability of investment in human capital (Propensity score) for each firms. These propensity scores will be applied to make comparison between treatment units and control units.

PSM method uses a variety of techniques to compare results of treatment and control group. Each technique has its own advantage and limitation. We calculate the impact by using different techniques to check the consistency. The research employed two techniques including Stratification and Kernel Matching method with Bootstrapped standard errors that are better the other one in PSM methods (Khandker, 2010).

Table 2 showed the results on impact of off-the-job training (with and before 2008) on revenue, profit and ROA (in $2008,2009,2010)$ for the case of formal enterprises. Both techniques showed that for the case of formal enterprises, there is no statistical evidence to state that training activities have positive impact on revenue, profit in 2008, 2009 or 2010. However, training was found to improve the return on asset (ROA) in 2008 from 9.3 to 9.7 percentage point.

Table 2. Average Treatment Effect for the Treated (ATT) of the training using PSM

\begin{tabular}{cccc}
\hline & \multicolumn{3}{c}{ Year } \\
\hline Stratification method & 2008 & 2009 & 2010 \\
Performance outcomes & & & \\
Ln(Revenue) & 0.121 & 0.185 & 0.248 \\
Ln(Profits) & {$[1.449]$} & {$[1.113]$} & {$[1.483]$} \\
& 0.207 & 0.107 & 0.121 \\
Financial outcome & {$[1.417]$} & {$[0.598]$} & {$[0.702]$} \\
ROA & $9.561^{*}$ & 9.562 & 5.329 \\
\multicolumn{2}{c}{ Kernel matching \& Bootstrapped SE } & {$[0.903]$} & {$[0.518]$} \\
Performance outcomes & & \\
Ln(Revenue) & 0.181 & 0.140 & 0.209 \\
Ln(Profits) & {$[1.057]$} & {$[0.705]$} & {$[1.346]$} \\
Financial outcome & 0.202 & 0.073 & 0.086 \\
ROA & {$[1.231]$} & {$[0.432]$} & {$[0.432]$} \\
& $9.325^{*}$ & 6.73 & 1.212 \\
& {$[1.678]$} & {$[0.511]$} & {$[0.083]$} \\
\hline
\end{tabular}

Notes:*significant at 10\% level, ${ }^{*}$ significant at $5 \%$ level, ${ }^{\star * *}$ significant at $1 \%$ level; t-statistics in [ ]

+With stratification matching, n.treatment=112, n.control=387 formal enterprises

+With Kernel matching \& Bootstrapped SE, n.treatment=112, n.control=386 formal enterprises

Source: Calculated from CIEM data $(2010,2012)$ 
There is no evidence to conclude that off-the-job training has positive impact on revenue and profit for the case of formal enterprises. The reasons may be due to fact that their management and evaluation on training activities is not good, and their labor-force management skill is not professional; or originated from the economic recession which hinders the firms' operation. Moreover, due to higher unemployment rate, it is not difficult for the firms to recruit good-quality employees in labor market, so the firms do not pay much attention to training. Therefore, their program may be not good, which results in the less effectiveness of training program. Off-the-job training does not improve revenue and profit of SMEs, which may be caused by the fact that SMEs do not pay attention to this kind of training but only focus on on-the-job training.

However, off-the-job training is also beneficial to SMEs because it enhances firms' effectiveness regarding financial aspect (e.g. ROA). This seems that training helps these firms to make use of their resources as well as improve the effectiveness of equipment and materials in order to maintain firms' operation and survive under the period of global crisis. In the context of economic recession, it may be difficult for SMEs to improve firms' revenue and profit. Therefore, off-the-job training may not generate any increase firms' revenue or profit in the short term.

\section{Conclusion, Policy Implications and Further Study}

\subsection{Conclusion}

This research applied the data on training activity of SMEs in the survey of 2009. The enterprises who answered that they often organize short-term (less than 6 month) training programs for their current employees, or new employees stated that they have stable and clear training policies.

There is no statistical evidence to conclude that, for the case of the formal enterprises, training activities has significant impact on firms' revenue and profit in short term (in 2008), or in the near future (in 2009 and 2010); however, training activity is found to improve firms' ROA in short term (in 2008) from 9.3 to 9.7 percentage point.

This result is consistent with findings by Storey (2002) for the case of SMEs in UK, and by Black and Lynch (2001). However, this result is inconsistent with the research by Nguyen et al. (2008) for the case of firms in Vietnam. The insignificant impact of training on performance in this paper does not support the universalistic perspective in SHRM theoretical model.

\subsection{Policy implication}

SMEs Assistance Center of the Ministry of Planning \& Investment as well as Organizations with the function of supporting SMEs, the Vietnam Chamber of Commerce and Industry (VCCI) should pay more attention on the policies of encouraging the SMEs to conduct training activities on modern labor force management as well as other management skills (they currently focus on such activities as business start-up, business registration). The forums and conferences should be held in other for concerning parties to share their experience. Thenceforth, SMEs can design and conduct their training program more effectively.

Universities, colleges, vocational training schools as well as teaching staff need to improve the quality of training linking between theory and practice; improve their marketing activities, and have good connection with the enterprises for receiving more practical and efficient support via such contracts as consultancy, training, scientific research and technology transfer as well as providing good-quality labor force to the enterprises.

Short-term formal training has positive impact on firms' ROA only in short term, but there is no positive impact on firms' ROA in the near future. Therefore, training activity should be conducted regularly and the managers in firms need to support and encourage their staff to apply knowledge, skills as well as have good working incentive after training. The enterprises also need to pay attention on determining the demands for training, planning training schedule, design training program, selecting trainers, selecting appropriate employees for each course, organizing training courses, evaluating the training process, or cooperating with experts and universities in order to have better training activities.

The effectiveness of training activities regarding the improvement of revenue and profit is insignificant. It may come from the fact that the SMEs do not pay much attention to training activities as well as their effectiveness; only few firms have obvious training plans, and most of the firms have not established an appropriate connection between these plans with human resource management (recruitment, training, wage, motivation, work allocation, etc.,) as well as the administration activities of the firms. It seems that some firms consider training activities as a chance to get disbursement, enjoy some free tours, and obtain personal benefits rather than as an opportunity to improve firm's effectiveness and productivity.

The group of qualified organizations, experts, instructors, and trainers that meet requirements of the firms will also make a remarkable contribution to the increase in the effectiveness of training activities. Training program and training 
contents closely connected with each specific job or situation of each firm will enable their workers to apply new knowledge quickly. In addition to on-the-job or off-the-job training activities held by the firms, the firms can coordinate with training organizations/ institutions to establish a specific and appropriate training program rather than an unspecific one.

The support from the government in quality control and quality improvement of training courses supplied by educational organizations/ institutions, colleges, or universities will establish an efficient labor market, and a high-quality short-term training services. Thenceforth, firms can easily recruit and train labor force with high skill, good knowledge and appropriate attitude as well as save training cost and increase firms' performance and labor productivity.

\subsection{Further study}

The research will be improved if it conducts the impact evaluation of the most recent training activity (in the survey of 2011) on firms' performance and then compares with the results from training activities in the survey of 2009, using DID with PSM in order to reap the better results. Qualitative information should be applied to explain and reinforce the results.

SMEs consists of formal enterprises and household businesses. Further studies may analyze the case of household business, and then compare the impact of training activities between both business groups regarding other indicators such as productivity, export value, innovation, etc

\section{Acknowledgments}

This work is carried out through a research grant and technical support from the Mekong Economic Research Network - a research initiative managed by the Centre for Analysis and Forecasting (CAF) of the Vietnam Academy of Social Sciences (VASS) with financial support from the International Development Research Centre (IDRC), Canada.

The authors are grateful for helpful comments and suggestions by Dr. Nguyen Ngoc Anh, Dr. Sothea Oum, Dr. Xavier Oudin, Dr. Laure Pasquier-Doumer, Dr. Nguyen Hoang Bao, Dr. Nguyen Huu Lam, Dr. Pham Khanh Nam, Mr. Pham Ngoc Toan, Mr. Vu Hoang Dat, Mr. Hoang Van Viet and participants at the final networking meeting of MERN, Phnom Penh, Cambodia 8-9 September 2014.

\section{References}

Acemoglu, D. \& Pischke, J.S.(1999). The structure of wages and investment in general investment. Journal of political Economy,107(3),539-572.

Central Institute for Economic Management - CIEM (2010). Characteristics of the Vietnamese business climate: Evidence from a SME survey in 2009.Tai Chanh Publisher.

Ballot, G., Fathi, F.\& Taymaz, E. (2001). Firms' Human Capital, R\&D and Performance: A Study on French and Swedish Firm. Labour Economics, 8, 443462.

Barney, J.B., \& Wright, P.M. (1998). On Becoming a Strategic Partner. HumanResource Management, 37, 31-46.

Baron, I.N. \& Kreps, D.M. (1999). Consistent Human Resource Practices. California Management, 41, 29-53.

Black, S.E. \& Lynch, L. M. (2001). How to Compete: The Impact of Workplace Practices and Information Technology on Productivity. The Review of Economies and Statistics, 83(3), 434-445.

Dearden, L., Reed, H.\& Reenen, J. V. (2006). The Impact of Training on Productivity and Wages: Evidence from British Panel Data. Oxford Bulletin of Economics and Statistics 68(4), 397-421.

Dumas, A. \& Hanchane, S. (2010). How Does Job-Training Increase Firm Performance? The Case of Morocco. International Journal of Manpower, 31(5), 585-602.

Delery, J.E. \& Doty, D. H. (1996). Modes of Theorizing in Strategic Human Resource Management. Academy of Management Journal, 39, 802-835.

Forrier, A. \& Sels, L. (2003). Flexibility, Turnover and Training. International Journal of Manpower, 24 (2), 148-168.

GSO (2012). Report on Labor Force Survey in 2011. Department of Population and Labour Statistics,Vietnam General Statistics Office.

Guidetti, G. \& Mazzanti, M. (2007). Firm-Level Training in Local Economic Systems Complementarities in Production and Firm Innovation Strategies. The journal of Socio-Economics, 36, 875-894.

Hansson, B. (2007). Company-Based Determinants of Training and the Impact of Training on Company Performance: Results from an International HRM Survey. Personnel Reviews, 36 (2), 311-331.

Hellerstein, J.K., Neumark, D., \&Troske, K. R. (1999). Wages , productivity and worker charateristics: Evidence from plant level production functions and wage equations. International Economics Review, 40(1), 95.

Jones, J. T.(2005). The Determinants of Training in Australian Manufacturing SMEs.Education and training, 47(8), 605-615.

Khandker, S.R., Koolwal, G. B.\& Samad, H.A. (2010), Handbook on Impact Evaluation - Quantitative Methods and Practices. The World Bank.

Konings, J. \& Vanormelingen, S. (2011). The Impact of Training on Productivity and Wages: Firm Level Evidence.Working paper, IESE Business School and HU Brussels. [Online] Available: http://ttp.iza.org/dp4731.pdf.

Lepak, D.P. \&Snell, S. A. (1999). The Human Resource Architecture.Academy of Management Review, 24, 31-48.

Le Thi My Linh (2009). Human resource development in small and medium enterprises in Vietnam in the process of economic integration.Unpublished doctoral dissertation, National University of Economics.

Lucas, R.E. (1988). On the Mechanics of Economic Development. Journal of Monetary Economics, 22(1), 3-42.

Nguyen Tung (2012). HR practices and performance of small and medium enterprises in Vietnam. Working paper, Available: http://www.prompt.vn/anh/sharedocument/1003135115Quan\%20tri\%20nhan\%20su\%20tai\%20cac\%20SME\%20Viet\%20Nam.pdf (June 26, 2012)

Nguyen, N.T., Ngo, V.T. \& Buyens, D. (2008). The Impact of Training on Firm Performance: Case of Vietnam. Working paper, the $7^{\text {th }}$ International Conference of the Academy of Human Resource Development, Bangkok, Thailand. [Online] Available: 
http://www.feb.ugent.be/nl/Ondz/wp/Papers/wp_08_538.pdf_November 3-6, 2008)

Ostroff, C. \& Bowen, D. E. (2000). Moving HR to a Higher Level: HR Practices and Organizational Effectiveness, in K.J.Klein, \& S.W. Kozlowski (eds.), Multilevel Theory, Research, and Methods in Organizations(211-266). San Francisco, CA: Jossey-Bass.

Rosholm, M., Nielsen, H. S. \&Dabalen, A. (2005). Evaluation of Training in African Enterprises. Journal of Development Economics, 84, $310-329$.

Salas, E., \& Canon- Bowers, J.A. (2011). The science of training: A decade of progress. Annual Review of Psychology, 52, 471-499

Schuler, R.S. (1989). Strategic Human Resource Management and Industrial Relations. Human Relations, 42, 157 -184.

Storey, D.J. (2002). Education, Training and Development Policies and Practices in Medium-Size Companies in UK: Do They Really Influence Firm Performance? Omega - The International Journal of Management Science, 30, 249-264.

Tran Kim Dung (2011). Training and human resource development in enterprises in Ho Chi Minh. Working paper, University of Economics HCMC.

Tharenou, P., Saks, A.M.\& Moore, C. (2007). A Review and Critique of Research on Training and Organizational-Level Outcomes. Human Resource Management Review, 17, 251-273.

Wright, P.M. \& McMahan, G. C. (1992). Theoretical Perspectives for Strategic Human Resource Management. Journal of Management, 18, 295-320.

Xuan Ngoc (2012). The enterprise has spent more money for training.[Online] Available:http://vnexpress.net/gl/kinh-doanh/2012/04/ doanh-nghiep-do-tiencho-dao-tao-noi-bol (June 25, 2012)

\section{Appendix A}

Table 4. Probit Model of the Determinants on Investment in Human Capital

\begin{tabular}{|c|c|c|c|c|}
\hline & Coef. & $z$ & Marginal Effects & Mean \\
\hline Inassets & 0.039 & 0.53 & 0.00745 & 7.304 \\
\hline firmage & $-0.035^{\star \star \star}$ & -2.91 & -0.00680 & 10.729 \\
\hline industrialpark & -0.233 & -0.99 & -0.04023 & 0.120 \\
\hline cooperative & 0.218 & 0.70 & 0.04663 & 0.090 \\
\hline Itd_jstock & $-0.654^{\star \star \star}$ & -3.40 & -0.14571 & 0.692 \\
\hline officeworkers & -0.317 & -0.52 & -0.06110 & 0.247 \\
\hline casuallabour & 0.367 & 0.98 & 0.07063 & 0.112 \\
\hline turnover & -0.003 & -0.57 & -0.00048 & -1.318 \\
\hline restructure & $0.555^{\star \star}$ & 2.43 & 0.13448 & 0.122 \\
\hline businessplan & 0.319 & 0.55 & 0.05077 & 0.973 \\
\hline crisis & 0.003 & 0.02 & 0.00061 & 0.805 \\
\hline constraints & $-0.584^{\star *}$ & -2.37 & -0.14620 & 0.917 \\
\hline govassistance & -0.024 & -0.14 & -0.00451 & 0.376 \\
\hline foreigndonors & -0.031 & -0.14 & -0.00589 & 0.147 \\
\hline association & 0.166 & 0.90 & 0.03374 & 0.240 \\
\hline network & -0.071 & -0.41 & -0.01394 & 0.721 \\
\hline union & $0.382^{\star \star}$ & 2.08 & 0.08136 & 0.272 \\
\hline shorttermcon & $0.006^{\star *}$ & 2.01 & 0.00112 & 13.533 \\
\hline R\&D & -6.191 & -1.38 & -1.19137 & 0.005 \\
\hline moderntechnology & $-0.586^{\star *}$ & -2.08 & -0.11271 & 0.258 \\
\hline newspaperad & 0.315 & 1.58 & 0.06864 & 0.156 \\
\hline localauthorities & 0.428 & 1.08 & 0.10289 & 0.029 \\
\hline emcenter & -0.08 & -0.31 & -0.01484 & 0.086 \\
\hline diffrecruiting & $0.505^{\star \star \star}$ & 3.14 & 0.11017 & 0.288 \\
\hline healthsocialins & $0.402^{\star \star}$ & 2.16 & 0.07558 & 0.553 \\
\hline etrading & -0.201 & -0.85 & -0.03514 & 0.120 \\
\hline computer & $0.063^{\star \star \star}$ & 3.41 & 0.01204 & 3.376 \\
\hline jobrotation & $0.479^{\star \star}$ & 2.35 & 0.11160 & 0.144 \\
\hline servoutside & $0.603^{\star \star \star}$ & 2.59 & 0.08998 & 0.841 \\
\hline inventory & -0.011 & -0.21 & -0.00215 & 3.827 \\
\hline improveproducts & -0.049 & -0.32 & -0.00944 & 0.587 \\
\hline envstandard & $0.406^{\star \star}$ & 2.38 & 0.08763 & 0.261 \\
\hline Dummies for industry & Yes & & & \\
\hline Const. & $-1.482^{\star}$ & -1.69 & & \\
\hline Mean VIF & 1.37 & & & \\
\hline VIF max & 2.46 & & & \\
\hline Pseudo $\mathrm{R}^{2}$ & 0.30 & & & \\
\hline Count $\mathrm{R}^{2}$ & 0.84 & & & \\
\hline Balancing property & Satisfied & & & \\
\hline $\mathrm{n}$ & 569 & & & \\
\hline
\end{tabular}

Notes: Italic variables are dummies;

*significant at 10\% level, **significant at 5\% level, ***significant at $1 \%$ level

Source: Calculated from CIEM data $(2010,2012)$ 